\title{
RIBEIRA, FOZ DA CIDADE: APONTAMENTOS SOBRE O PROJETO SUBMETIDO AO CONCURSO BID URBANLAB 2017
}

\section{RIBEIRA, DESEMBOCADURA DE LA CIUDAD: ANOTACIONES SOBRE EL PROYECTO SOMETIDO AL CONCURSO BID URBANLAB 2017}

\section{RIBEIRA, ESTUARY OF THE CITY: NOTES ON THE PROJECT SUBMITTED TO THE 2017 BID URBANLAB COMPETITION}

\section{BEZERRA JÚNIOR, FRANCISCO DA ROCHA}

Professor Substituto do Departamento de Arquitetura e Urbanismo (UFRN), Mestrado em Arquitetura, Projeto e Meio Ambiente (PPAPMA/UFRN), arqchicojunior@gmail.com

\section{DIONISI, ALESSIO PERTICARATI}

Aluno especial do Programa de Pós-Graduação em Arquitetura e Urbanismo (PPGAU UFRN), alessiopdionisi@gmail.com

\section{ARAUJO, RENATA DE OLIVEIRA}

Mestranda no Programa de Pós-Graduação em Arquitetura e Urbanismo (PPGAU UFRN), renatadeoaraujo@gmail.com

\section{INTRODUCCÃO}

BID UrbanLab é um concurso destinado a universitários e jovens profissionais, a fim de buscar soluções para problemas urbanos da América Latina. As duas primeiras edições internacionais do concurso ocorreram em 2015, no bairro de Curundú, Panamá, e em 2016, na cidade de Santa Maria, Colômbia. A primeira edição nacional foi lançada em 2017, na cidade de Natal/RN, e buscou o desenvolvimento de um projeto urbanístico, social e patrimonial, inovador e sustentável, numa área de intervenção situada na Ribeira. O objetivo deste artigo é apresentar o projeto "Ribeira: Foz da Cidade"1, desenvolvido para o UrbanLab de 2017, e contemplado com Menção Honrosa. A apresentação da proposta se dará da seguinte forma: apresentação das problemáticas identificadas pelos autores no bairro, seguidas das soluções projetuais propostas pela equipe.

\section{CONCEITO}

Uma das particularidades urbanas mais significativas do bairro Ribeira é sua histórica desconexão visual e física com o Rio Potengi. Como possibilidade de reverter este cenário, foi proposto o conceito "delta" que, relaciona a ideia de fluidez, conexão, encontro e percurso. Buscou-se, ainda, a criação de espaços, denominados "nascentes", associadas à ideia de surgimento na superfície, de atividades culturais, lazer, educação, moradia e comércio, dando origem a cursos d'água que fluem no bairro em direção ao Potengi. Esses espaços configuram-se como polos locais indutores de desenvolvimento e concentram as principais ações do projeto. Iniciando-se nas nascentes as intervenções convergem, de forma análoga a um delta do rio, para o ponto central da proposta: A Nova Orla do Potengi (Figura 1). 
Figura 1: As Nascentes e o Delta.

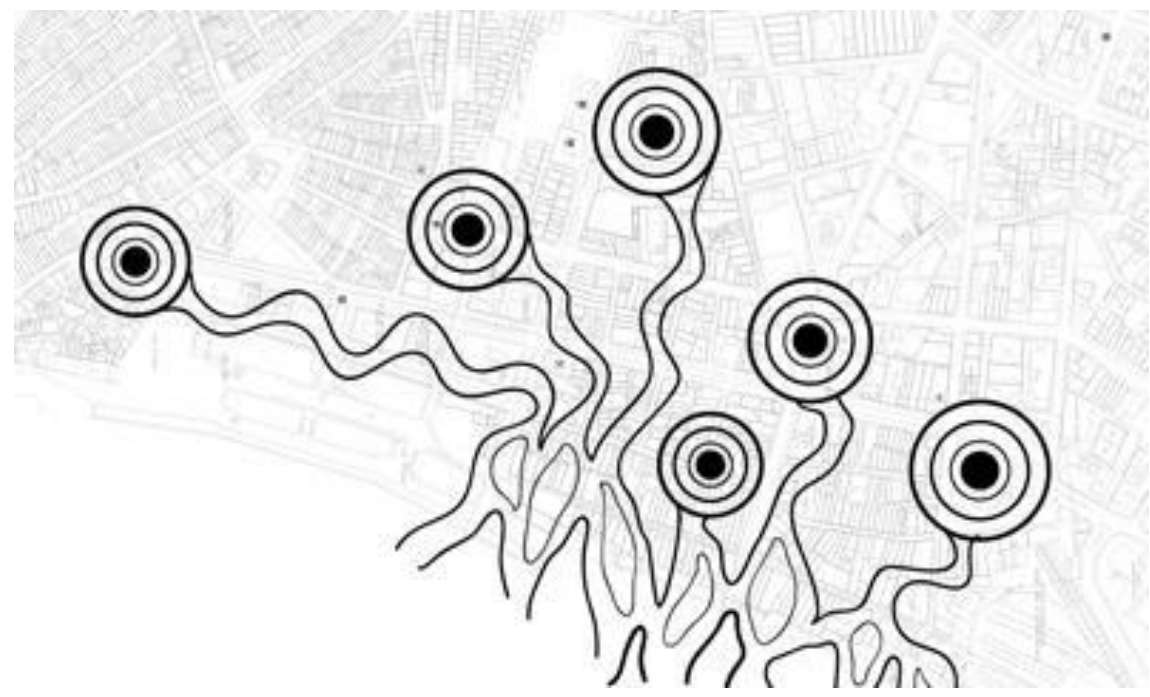

Fonte: Acervo dos autores.

Essa analogia ao delta é fortalecida pela configuração da implantação da Ribeira, inserida em uma área baixa da cidade. Nesse sentido, o bairro funcionaria como um receptor de vários canais ou braços do leito do rio pertencentes a outras áreas de Natal, favorecendo o acúmulo e os aluviões de cultura e desenvolvimento na foz da Ribeira.

\section{INTERVENÇÕES DE ÂMBITO GERAL}

A partir de uma abordagem multissetorial de ações, priorizando-se uma intervenção social, econômica e ambientalmente sustentável, a proposta apresentada para o Concurso pautou-se na identificação das problemáticas existentes e na recognição dos aspectos culturais, históricos, econômicos e socioambientais da Ribeira. O cruzamento desses elementos, agregado às estratégias de sustentabilidade, norteou a abordagem do projeto, caracterizada pelas seguintes categorias de intervenção: mobilidade urbana; patrimônio edilício e paisagístico; habitação, emprego e renda; espaços públicos e equipamentos urbanos, culturais, sociais e esportivos. Propuseram-se, ainda, ações nas imediações do polígono de intervenção definido pelo concurso, justificadas pelo potencial de uso de algumas edificações e áreas subutilizadas e por promover uma melhor articulação socioespacial entre os bairros adjacentes à Ribeira.

No que se refere às macros intervenções, ressalta-se a importância de desenvolver um novo reordenamento do sistema de circulação que minimizasse os conflitos de usos e a ostensiva prioridade pelos deslocamentos veiculares, sobretudo os automóveis. Esses últimos sobrecarregam as conexões entre os bairros (principalmente entre a zona norte e o centro da cidade) e desestimulam a circulação peatonal e cicloviária. Neste sentido, propõe-se um binário formado pela Avenida Duque de Caxias e a Rua Almino Afonso (Figura 2), cuja função é otimizar os fluxos no sentido bairro/centro e centro/bairro e áreas próximas. Propõe-se ainda a alteração na estrutura viária através da implementação de corredores de ônibus, ciclo faixas e bicicletários, alargamento e reestruturação das calçadas, implantação de estacionamentos subterrâneos e/ou edifícios garagens, além de um sistema de transporte marítimo através de balsas fluviais, possibilitando mais uma forma de interligação do bairro Ribeira com a zona administrativa Norte de Natal, separados pelo Rio Potengi. Almeja-se assim, uma plena integração entre os diversos modais e a ampla garantia da acessibilidade urbana.

A proposta projetual, no âmbito de ações locais, era pautada em 05 (cinco) nascentes (Socioeconômica, Eventos e Transporte, Habitacional e Esportiva, Cultural, Religiosa) e a Orla do Rio Potengi, conforme descritas a seguir. 
Figura 2: Proposta de Mobilidade Urbana

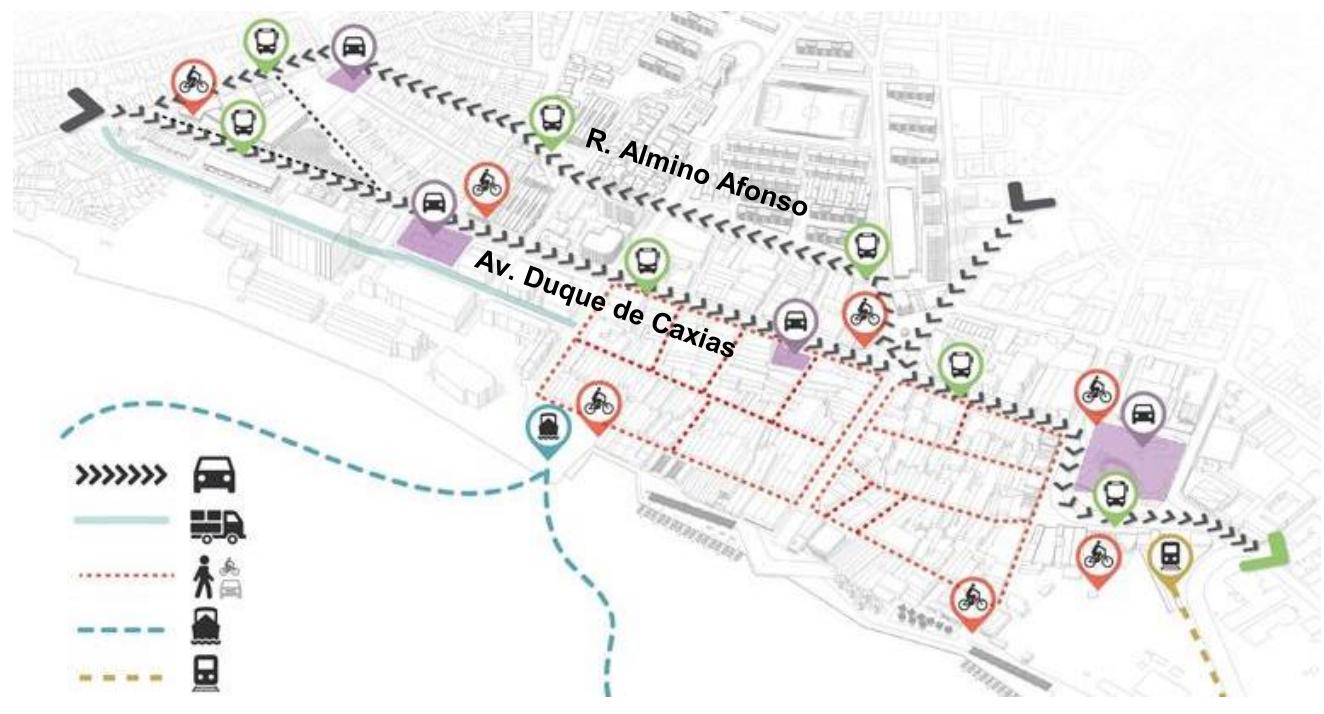

Fonte: Acervo dos autores

\section{NASCENTE SOCIOECONÔMICA}

A Nascente Socioeconômica emerge a fim de ter um papel na estruturação socioespacial entre a Ribeira e áreas de entorno (Mercado e a Feira das Rocas, o Hospital dos Pescadores, a área desocupada da Comunidade do Maruim, o Mercado do Peixe e do Canto do Mangue ${ }^{2}$ ). Nesse universo, a proposta busca, ao mesmo tempo, potencializar e resguardar as vocações pré-existentes do local, voltando-se as intervenções para duas esferas principais: a social - caracterizada pela implantação do Centro Comunitário dos Pescadores (CCP) - e a econômica - caracterizada pela alteração no entorno imediato do Mercado das Rocas. Como proposta de projeto, os galpões subutilizados foram adaptados para receber o CCP (Figura 3, "Centro Comunitário dos Pescadores"), cujo objetivo principal é preservar e divulgar os saberes relacionados à pesca artesanal. Esse espaço funcionaria como uma ponte para reconexão da comunidade do Maruim (realocada no Conjunto Habitacional São Pedro) e demais populações tradicionais vinculadas às atividades pesqueiras. O CCP dispõe de espaços para cursos de captação, biblioteca, manutenção e produção de pequenas embarcações, salas para atividades multiusos, salas para reuniões; à sua frente, estende-se uma praça pública identificada por um novo marco - uma escultura com tema relacionado à pesca (Figura 3, "Escultura"). Através da restrição do tráfego de veículos proposta para o local, espera-se um aumento no fluxo de pedestres entre os equipamentos públicos e, principalmente, diante das novas possibilidades de apropriação desses espaços.

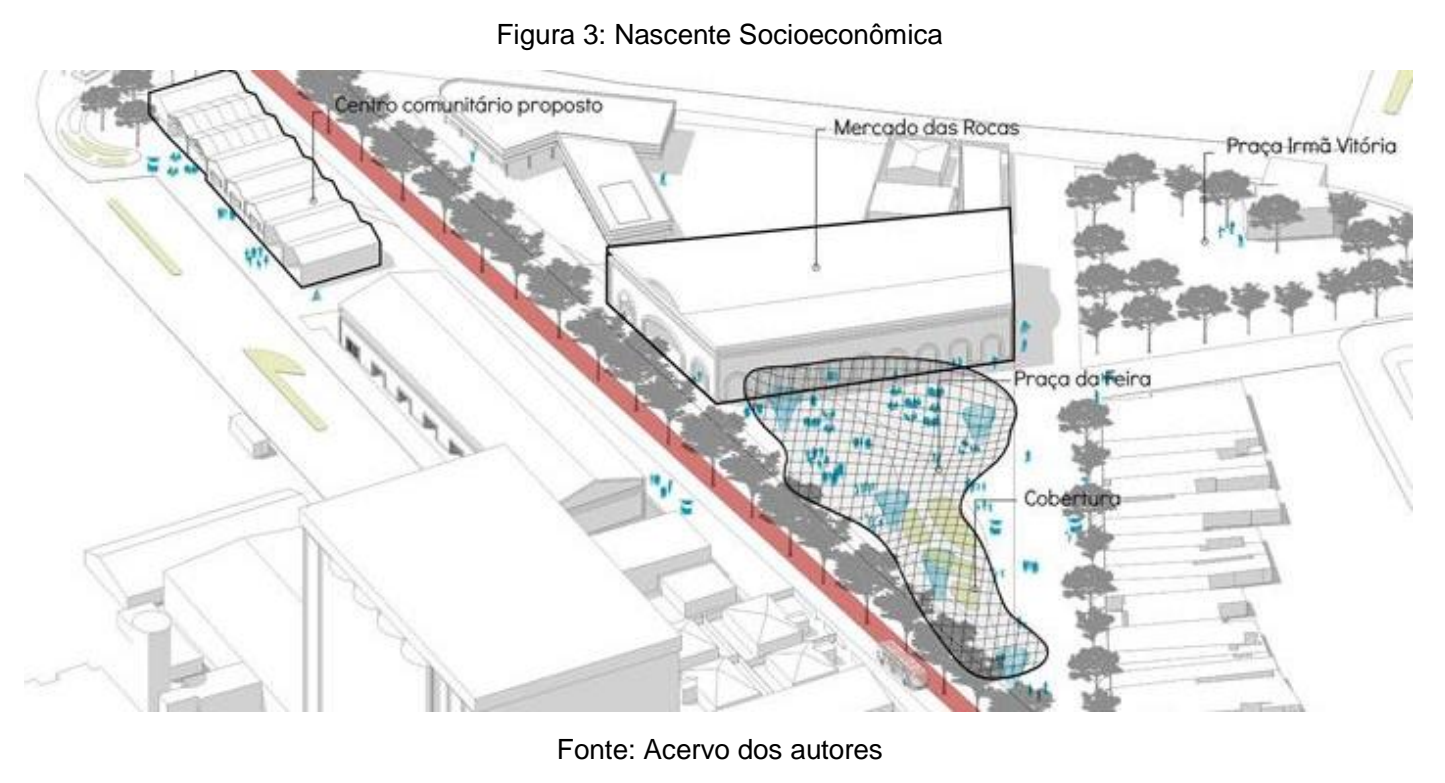


Figura 4: Nascente Socioeconômica

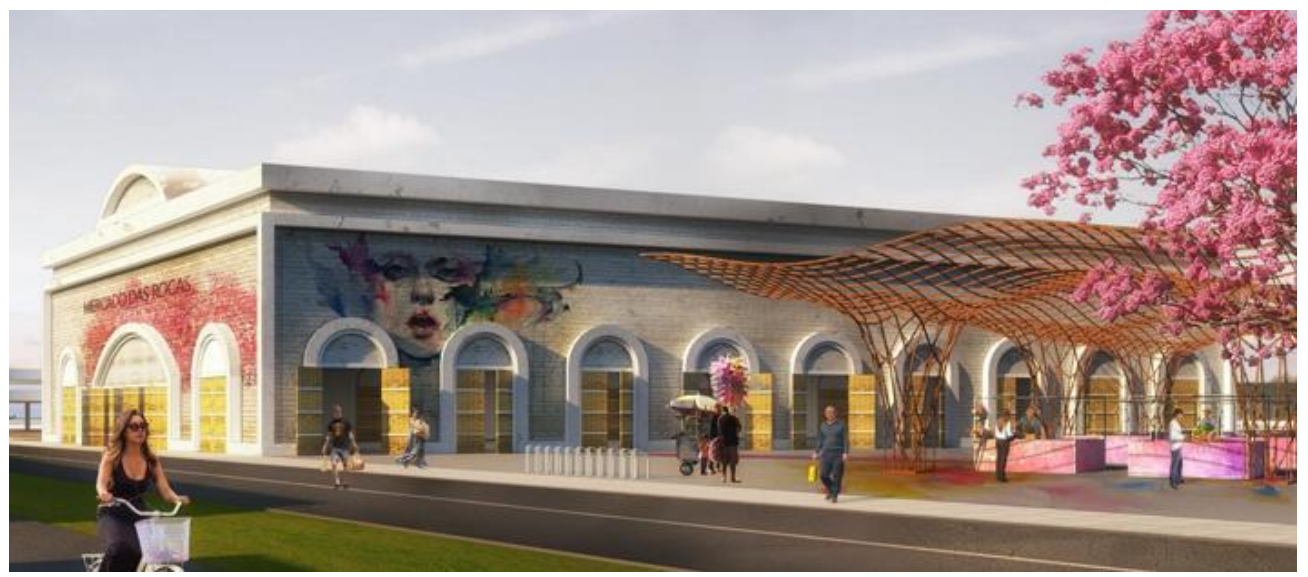

Fonte: Acervo dos autores

\section{NASCENTE DE EVENTOS E DE TRANSPORTES}

A praça Augusto Severo, local da Nascente de Eventos e de Transportes, é hoje o principal ponto nodal do bairro Ribeira. A Praça articula espacialmente os edifícios históricos que the circundam, conectando e distribuindo os fluxos viários entre a parte baixa e alta da cidade. Nessa área, propõe-se uma intervenção com o propósito de tornar eficiente a integração entre diferentes modais e de valorizar a vocação da praça à realização de eventos de grande porte.

O sistema viário adjacente à praça foi reorganizado, priorizando a circulação de modais não motorizados, principalmente de pedestre, e a acessibilidade aos distintos meios de transporte existentes na área. As calçadas foram reestruturadas para permitir o fácil acesso à estação de trens urbanos, aos pontos de ônibus, ao novo bicicletário, ao estacionamento coberto proposto (Figura 4, "Acesso ao estacionamento subsolo") e à conexão com sistema de circulação fluvial proposto que ocorreria no Terminal Marítimo. A superfície da praça foi ampliada até o alinhamento com os edifícios históricos, deslocando o trânsito veicular existente para a Av. Rio Branco, de forma a valorizar a circulação peatonal e o conjunto patrimonial edificado e paisagístico. Outra proposta, é a criação de uma Central do Cidadão com equipamentos de apoio à população e ao turista, localizada no prédio atualmente ocupado pelo Museu Djalma Maranhão. O exterior da Central será adaptado para se tornar palco e cenário do teatro de arena proposto para a praça (Figura 4, "Central do Cidadão" e "Teatro de Arena") e contaria ainda com uma cortina de água na fachada, fazendo referência a nascente do bairro naquele espaço. A proposta contempla um novo mobiliário urbano no local e a inclusão de vegetação nas áreas de permanência.

Figura 5: Nascente de Eventos e de Transporte

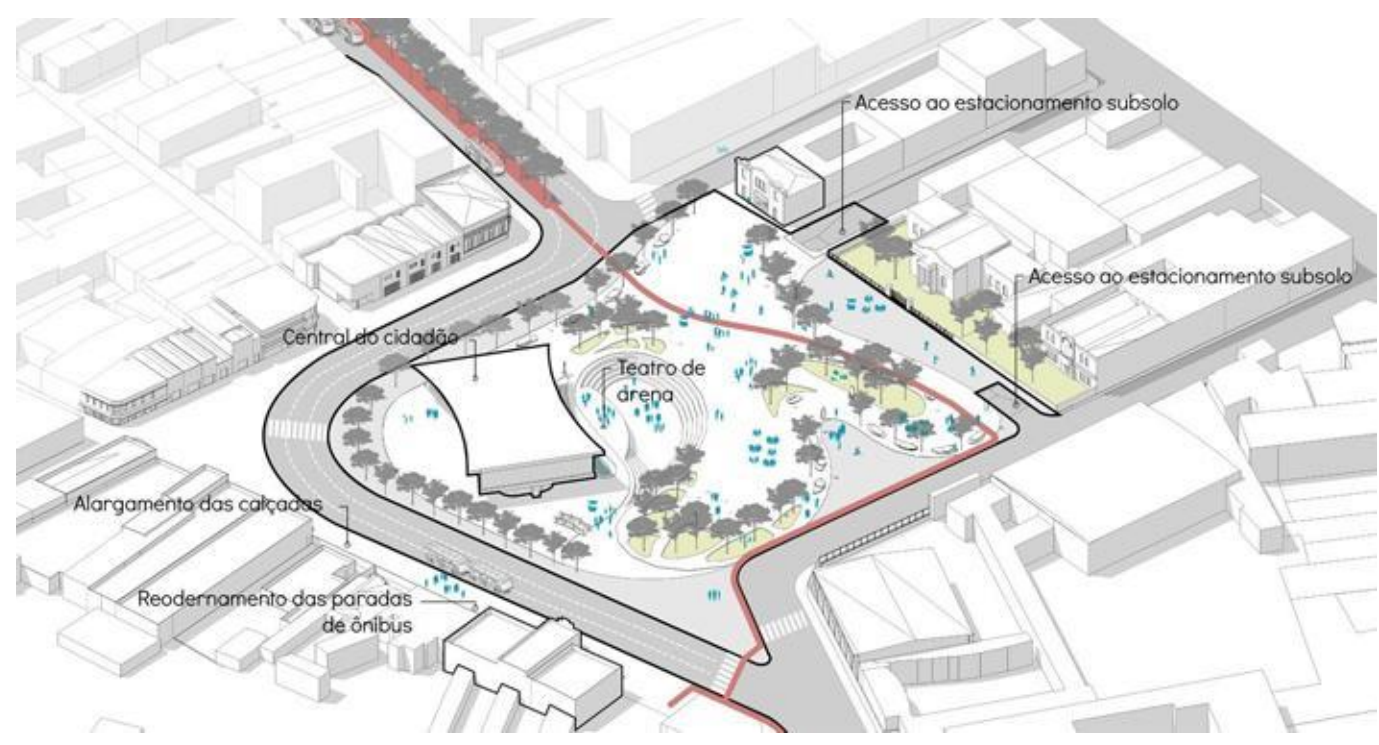

Fonte: Acervo dos autores 
Figura 6: Nascente de Eventos e de Transporte

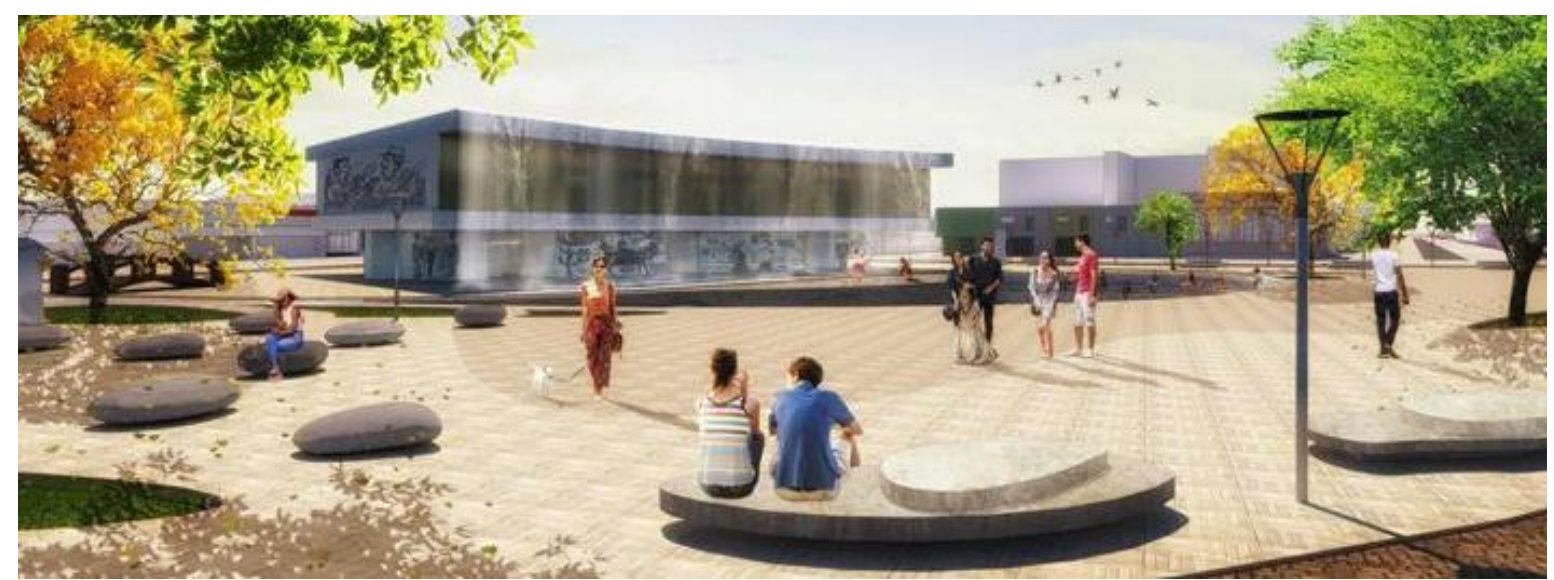

Fonte: Acervo dos autores

\section{NASCENTE HABITACIONAL E ESPORTIVA}

Alguns aspectos existentes nas imediações do Estádio de Futebol João Câmara determinam uma dinâmica urbana particular da Nascente Habitacional e Esportiva. De um lado, há a proximidade com o modelo habitacional produzido pelo mercado imobiliário, cujas construções, intramuros, seccionam o tecido urbano e diminuem a vitalidade das ruas. De outro, há a presença do Conjunto Habitacional São Pedro (CHSP), localizado na Rua João Câmara, modelo dos programas habitacionais atuais (Minha Casa, Minha Vida) onde encontra-se a população realocada da comunidade do Maruim ${ }^{3}$. Os edifícios do conjunto têm baixa qualidade ambiental, espacial, estética e, sobretudo, é distante das atividades e das relações pré-existentes entre a comunidade e o rio, e sobretudo diminuindo a identidade cultural do bairro. Terceiro, a área é o ponto mais baixo de parte da bacia de drenagem proveniente da Cidade Alta e, historicamente, sofre alagamentos. Quarto, e último aspecto, é a existência de galpões e terrenos subutilizados.

Considerando-se o potencial para ocupação apresentado, devido ao grande índice de vacância e vazios urbanos, e a disponibilidade de infraestrutura propícia ao adensamento, projeta-se um novo modelo urbano: focado em edifícios de uso misto (comercial e/ou de serviço no pavimento térreo e residencial no superior), com tipologias habitacionais diversas, adaptadas às condicionantes climáticas e permeadas por áreas verdes, equipamentos de lazer e gabarito gradual (a fim de proteger a paisagem). Para resguardar a população do CHSP frente à valorização ocasionada pelas melhorias na região, propõe-se 0 enquadramento do conjunto numa Área Especial de Interesse Social (AEIS) ${ }^{4}$. O estádio existente, centro geográfico desta Nascente, será requalificado e funcionará também como uma lagoa de drenagem urbana, com um sistema preventivo de alagamento.

Figura 7: Nascente Habitacional e Esportiva

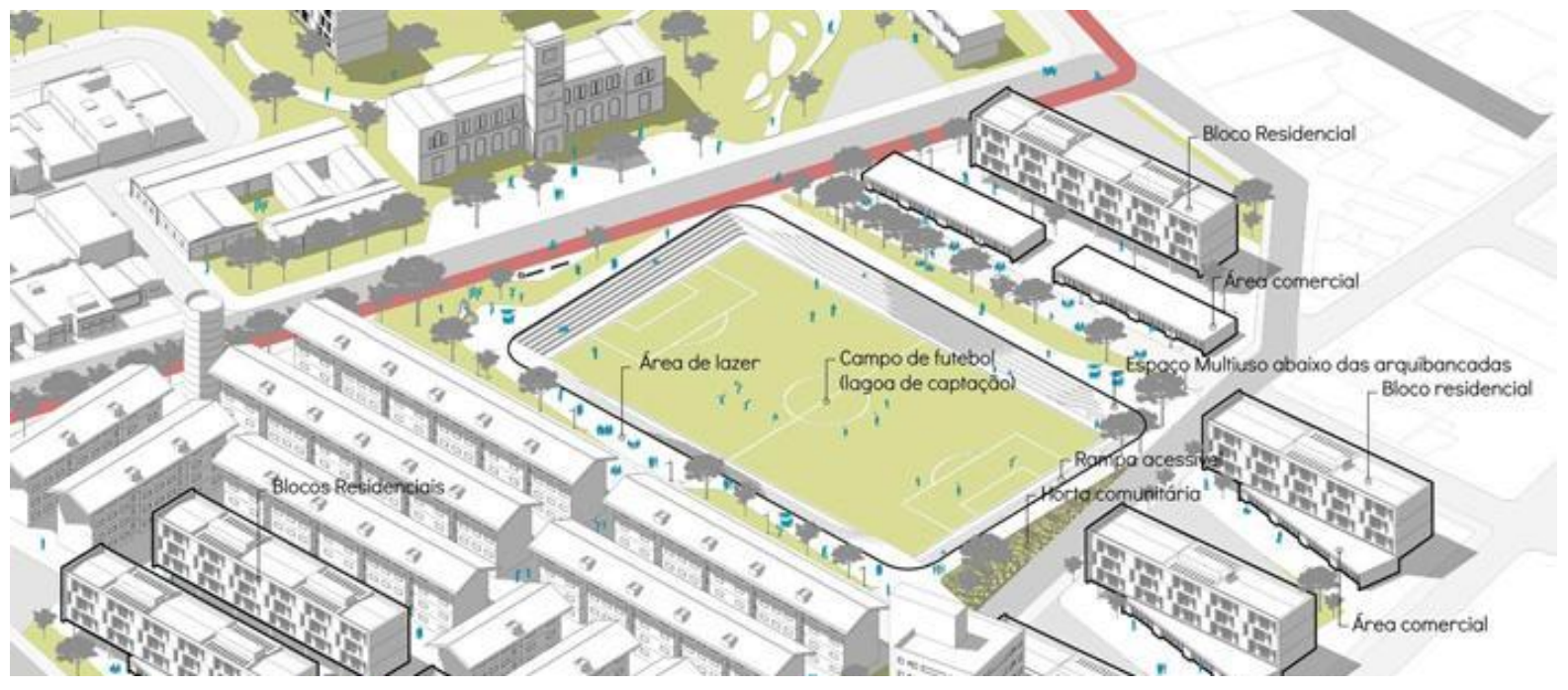

Fonte: Acervo dos autores 
Figura 8: Nascente Habitacional e Esportiva

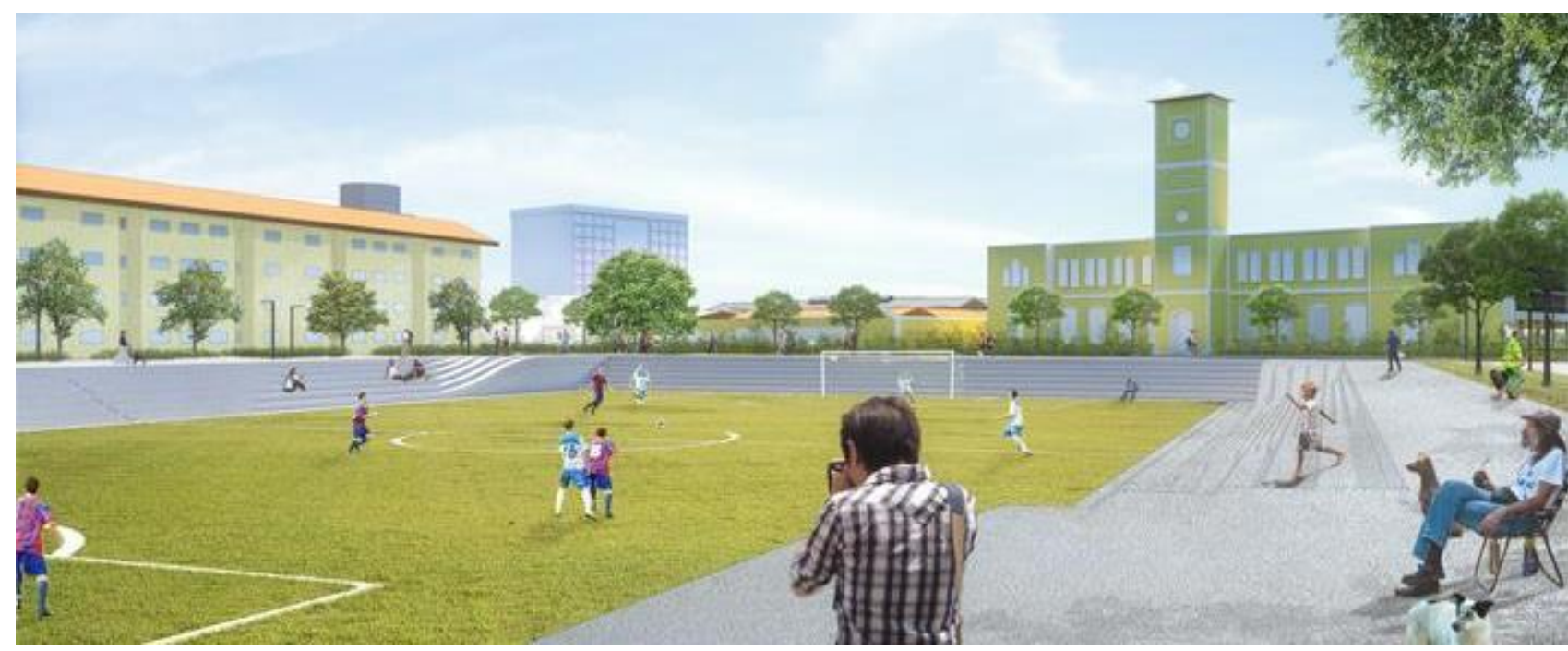

Fonte: Acervo dos autores

\section{NASCENTE CULTURAL}

A Ribeira foi no passado o principal ponto de chegada e partida de Natal, através do rio, ou pelo antigo sistema ferroviário. Deste último, restam duas edificações abandonadas e degradadas, localizadas no cruzamento das Ruas Olavo Bilac e Almino Afonso. A primeira, abrigava a Estação Ferroviária do bairro e a segunda, as oficinas de manutenção. É nesse local que se delimita a Nascente Cultural.

As características estruturais identificadas nestas construções (galpões), de grandes vãos, denotam potencial para abrigar atividades culturais, tais como: teatro e artes circenses. Assim, aventa-se a transferência do Museu de Cultura Popular Djalma Maranhão para as instalações dos antigos galpões das oficinas, com a possibilidade de uma área expositiva maior que a existente na edificação da Praça Augusto Severo. O edifício da antiga Estação Ferroviária abrigaria a Escola Pública de Artes da Ribeira, composta por ateliês para produção e ensino do artesanato e das artes regionais, além de oficinas de circo, dança e teatro, sobretudo voltada às tradições culturais locais. Entre os dois conjuntos de galpões, projeta-se uma praça pública destinada às apresentações artísticas e exposições, de maneira a estender livremente as atividades desenvolvidas nos galpões. O anfiteatro semienterrado é o ponto de emersão e símbolo desta nascente.

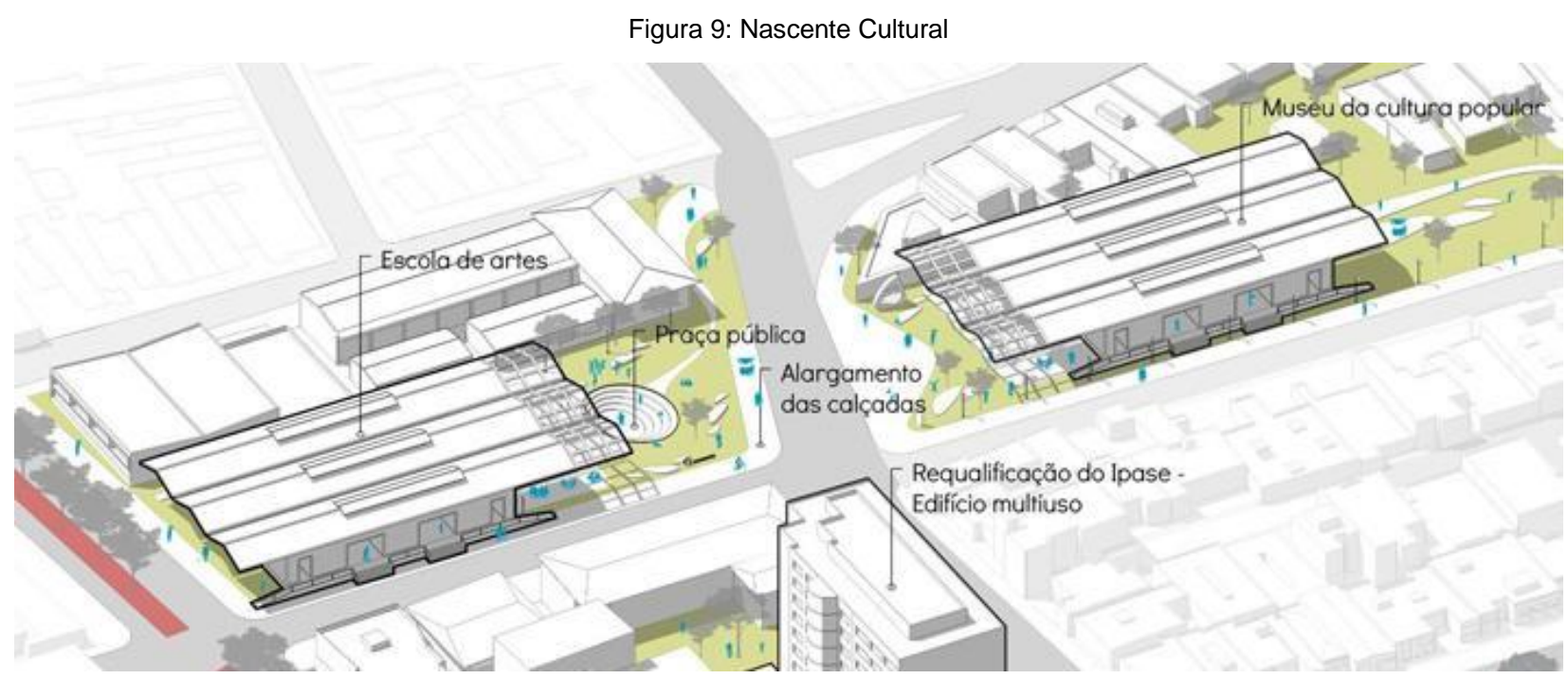

Fonte: Acervo dos autores 
Figura 10: Nascente Cultural

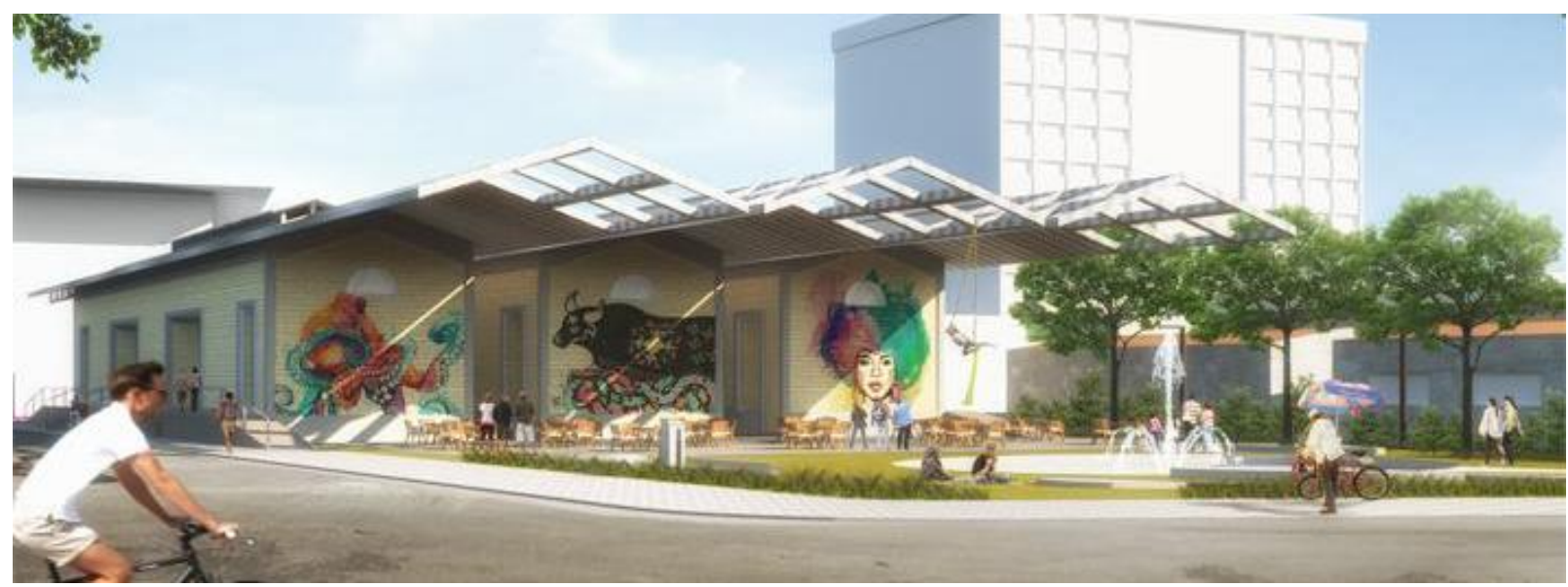

Fonte: Acervo dos autores

\section{NASCENTE RELIGIOSA}

A Igreja Bom Jesus das Dores, quarta igreja edificada em Natal no século XVIII, está localizada na Praça Capitão José da Penha, local definido como Nascente Religiosa. As consecutivas intervenções urbanas descaracterizaram tanto a praça quanto a percepção visual da igreja. Hoje, resta na paisagem poucos traços da sua concepção original: apenas uma estação elevatória de esgoto em estilo eclético. O centro da proposta dessa nascente é a readequação do sistema viário, deslocando o prolongamento da Av. Rio Branco para um ponto mais próximo a Av. Duque de Caxias, retomando a conformação espacial original da praça. $O$ paisagismo e o mobiliário existente serão requalificados a fim de agregar valor paisagístico e estético à área, preservando a vista da igreja Bom Jesus das Dores e das edificações de valor patrimonial no seu entorno.

Figuras 11 e 12: Nascente Religiosa
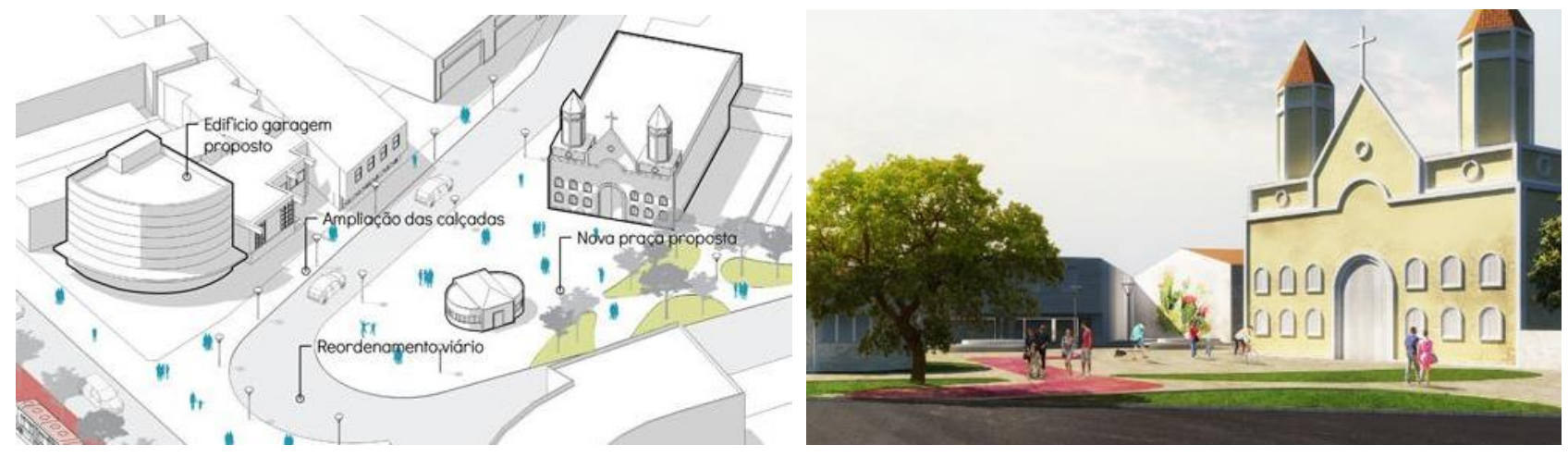

Fonte: Acervo dos autores

\section{NOVA ORLA DO POTENGI}

O Rio Potengi e o conjunto das edificações entre a Rua Chile e a Av. Duque de Caxias representam, hoje, um importante patrimônio ambiental e arquitetônico da cidade. O primeiro sofre com a poluição de suas águas e a falta de interação visual com a população. O segundo, salvo as raras iniciativas do setor privado, deteriorase a cada dia. A proposta para a Nova Orla do Potengi busca equacionar as problemáticas apontadas e, ao mesmo tempo, fomentar vocações existentes, como as atividades pesqueiras, culturais e artísticas presentes na área. A principal ação projetual é a criação de um novo equipamento urbano capaz de aproximar, visualmente, a cidade do rio, e induzir o desenvolvimento socioeconômico nas suas imediações. Esse espaço, localizado entre o Terminal Marítimo e o Pesqueiro, reordenaria o embarque e o desembarque dos barcos de pesca, proporcionando, assim, uma nova área pública de lazer para a moradores da cidade e turistas. Sugerese que o poder público incentive uma maior permeabilidade entre o térreo das edificações da Rua Chile e a orla do rio, com novos usos como bares, restaurantes, cafés e galerias de artes, possibilitando uma maior relação no nível do solo. A orla servirá também como uma via de conexão entre os modais localizados na 
Praça Augusto Severo e o Terminal Marítimo que, além de já receber as embarcações turísticas, passará a contar, nesta proposta, com um serviço de circulação fluvial até o bairro da Redinha, assim como a implantação de espaços adequados para as atividades pesqueiras existentes na orla do Potengi e o fomento e reconhecimento dessa atividade local no bairro.

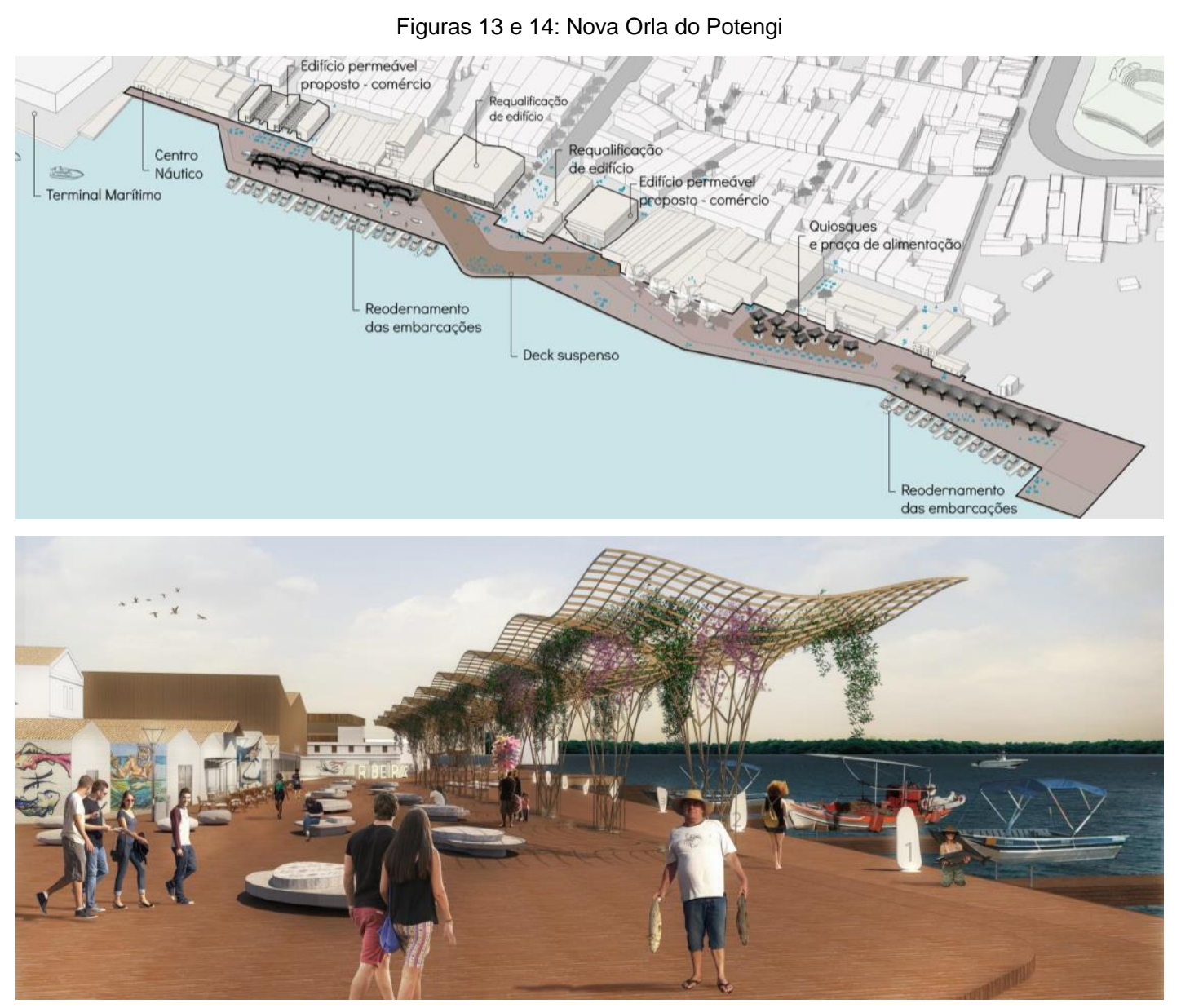

Fonte: Acervo dos autores

\section{CONSIDERAÇõES FINAIS}

As intervenções propostas exploram uma abordagem holística frente às problemáticas existentes na Ribeira, partindo das vocações inerentes ao bairro e expondo soluções que impactam nas suas atividades sociais, econômicas e de lazer. Espera-se que as soluções propostas contribuam para reverter o quadro de desemprego, sobretudo dos moradores da Ribeira e mitigar parte do déficit habitacional de Natal. À luz da sustentabilidade, as ações auxiliam na construção de uma maior qualidade ambiental e urbana. A implantação do projeto foi orçada em $U \$ 17.315 .000,00$ e dividida em três fases principais: o projeto, a captação de recursos e a implementação. O tempo total previsto é de quarenta e oito meses. A exequibilidade do projeto baseia-se no uso do Fundo de Urbanização, destinado a programas de urbanização de AEIS e investimentos em saneamento e infraestrutura urbana; no Programa de Aceleração do Crescimento Cidades Históricas para as intervenções na poligonal de tombamento do IPHAN, contemplando a fração com maior concentração de edificações protegidas sob restrição da Zonas Especiais de Preservação do Patrimônio Histórico e Zona Especial de Preservação; nas parcerias públicas e privadas, através do instrumento de Consórcio com o objetivo induzir a ocupação de áreas já dotadas de infraestrutura e equipamentos, mais aptas para urbanizar ou povoar (evitando pressão de expansão horizontal na direção de áreas não servidas de infraestrutura ou vulneráveis, sob o ponto de vista ambiental); na implementação de instrumentos urbanísticos para inibir a gentrificação, incentivar a diversidade de uso e o adensamento, bem como assegurar a qualidade urbana das novas áreas habitacionais; nos sistemas indutores do desenvolvimento, que retroalimentam os investimentos públicos, tais como: Parcelamento, Edificação ou Utilização Compulsórios, IPTU progressivo no tempo, Transferência do Direito de Construir e Outorga Onerosa; e, por fim, nos incentivos fiscais e contrapartidas para implantação de estabelecimentos de comércio, serviço, cultura e habitação. 


\section{REFERÊNCIAS}

BID UrbanLab Natal - 1a Edição Nacional. Disponível em: http://convocatorias.iadb.org/pt/urbanlab-brasil/inicio-urbanlabbrasil Acesso em: 1ํ de Julho de 2018.

\section{NOTAS}

${ }^{1}$ Os autores da proposta "Ribeira: Foz da Cidade" foram os seguintes: Alessio Dionisi, Carolina Sousa, José Daniel Calderon, Lucas Pereira, Leonardo Dias e Renata Araújo. O desenvolvimento da proposta foi orientado e supervisionado pelo Prof. MSc. Francisco da Rocha Bezerra Júnior.

${ }^{2}$ Espaços localizados no bairro da Ribeira e Rocas representativos para identidade local e espacialmente reconhecidos.

${ }^{3}$ A comunidade do Maruim apresenta suas primeiras referências de ocupação da década de 1940, localizada à margem sul do rio Potengi, tendo como um dos marcos da sua ocupação a Colônia de Pescadores

${ }^{4}$ Segundo o Plano Diretor de Natal - Lei Complementar $n^{\circ} 082 / 2007$, art. $6^{\circ}$, as áreas especiais de interesse social (AEIS) se configuram a partir da dimensão socioeconômica e cultural da população, com renda familiar predominante de até 3 (três) salários-mínimos, definida pela Mancha de Interesse Social (MIS), e pelos atributos morfológicos dos assentamentos

NOTA DO EDITOR $\left({ }^{*}\right)$ O conteúdo do artigo e as imagens nele publicadas são de responsabilidade do(s) autor(es). 